\title{
Kinerja Kepala Sekolah dalam Meningkatkan Kualitas Pembelajaran di SMA Negeri 1 Kota Jambi tahun Pelajaran 2017/2018
}

\author{
Evariana \\ SMA Negeri 1 Jambi \\ Correspondence email: evariana1993@gmail.com
}

\begin{abstract}
Quality of learning will be created when the education organization can be implemented effectively in a conceptual framework. The effectiveness of education organizing will produce the quality of education that is expected in accordance with the vision, mission and objectives of the learning system held in the school. In improving the quality of school responsibility learning lies at the head of the school. A headmaster must be competent in his field and responsible for his duties. The principal as an educational leader has also acted as a consultant to teachers in solving their problems, the Headmaster continues to strive to improve the ability of teachers and staff to work and think together. As the principal's education leader continues to assist teachers to participate in the teaching program. The objectives of the study are: 1) Knowing how the school's performance form in improving the quality of learning in SMA Negeri 1 Jambi City Year lesson 2017/2018; 2) Knowing what are the obstacles facing the school principal in improving the quality of learning in SMA Negeri 1 Jambi City Year lesson 2017/2018. Based on the results of research and discussion it can be concluded that the principal in the context of organizing education has a very strategic role as a leader. Principals are responsible for improving the quality of learning. The school's performance in improving the quality of learning has been excellent. The headmaster as a creative leader should also improve the quality of learning such as the smoothness of thinking which includes: creating quality teachers, realizing the achievement of mission vision, planning achievement of objectives, managing and leveraging the school facilities and infrastructure, student management, curriculum management, and the implementation of IT systems. Furthermore, the headmaster in improving the quality of learning should have the flexibility of thinking which includes: responding to changes in the quality improvement of teachers, to empower existing resources for the achievement of mission vision, and the management of learning outcomes to produce outstanding graduates. Principals should also have elaboration to improve the quality of learning that includes: developing the organization and implementing school programs, and the headmaster must also have an originality in improving the quality of learning that includes: forming an organization for the achievement of the vision of the school mission and implementing class supervision.
\end{abstract}

Keywords: performance; headmaster; quality learning

\section{PENDAHULUAN}

Sebagai seorang pemimpin kepala sekolah memposisikan dirinya sebagai pelayan masyarakat dan tidak bersikap otoriter. Sebagaimana karakteristik sekolah yang berkualitas yakni fokus pada pelanggan serta menerapkan gaya kepemimpinan yang terbuka dan demokratis. Gambaran sederhana tentang keberadaan kepemimpinan pendidikan di atas menunjukkan bahwa dalam proses penyelenggaraan pendidikan yang baik mutlak diperlukan seorang kepala sekolah yang memiliki kemampuan, adalah kepala sekolah yang dapat menjalankan fungsi kepemimpinannya dengan baik demi terwujudnya pendidikan yang berkualitas, walau dalam prakteknya masih ditemukan berbagai catatan negatif tentang kepemimpinan kepala sekolah yang kurang menggambarkan kondisi ideal sebagai pemimpin pendidikan. Seorang kepala sekolah memiliki kompetensi profesional dalam memimpin organisasi di sekolah dengan tugas merencanakan, mengatur, dan mengevaluasi organsiasi dan bekerjasama dengan para komponen yang ada di sekolah yakni guru-guru dalam melaksanakan proses belajar mengajar sebagai upaya mencerdaskan kehidupan bangsa sebagai salah satu tujuan pendidikan. Adanya keprofesionalan kepala sekolah ini, pengembangan profesionalisme tenaga kependidikan akan mudah dilaksanakan berdasarkan tugas dan fungsi yang dimilikinya, kepala sekolah harus memahami kebutuhan atau keperluan sekolah yang ia pimpin sehingga kompetensi guru makin bertambah dan berkembang dengan pesat sehingga guru yang profesional terwujud adanya.

Melakukan pekerjaan dalam memimpin merupakan tugas mulia dari seorang kepala sekolah. Kepemimpinan kepala sekolah pada hakikatnya merupakan salah satu usaha memimpin untuk mendorong, mempengaruhi serta mengarahkan para guru, siswa serta pihak lain yang mendukung dunia pendidikan agar tercapai tujuan pendidikan yang didambakan bersama.

Dalam pelaksanaanya, seorang kepala sekolah dituntut agar mencapai keberhasilan dalam berbagai aspek yang mencakup pengelolaan sekolah yang profesional, kegiatan pembelajaran yang efektif, pengelolaan sarana dan prasana, pengelolaan ketenagakerjaan yang ada di sekolah, pengelolaan lingkungan sekolah yang nyaman, dan pengelolaan antara sekolah dengan masyarakat di sekitarnya dalam meningkatkan kulitas pembelajaran sehingga semua pihak bekerja sama mewujudkan program Kepala sekolah SMA Negeri 1 Kota Jambi salah satunya menghasilkan siswa siswi yang berkualitas yang memilki prestasi dan bisa masuk Perguruan Tinggi 
Unggulan serta bisa bersaing dengan sekolah sekolah unggulan lainnya.

Dalam Peningkatan kualitas merupakan usaha dari setiap lembaga lembaga penghasil produk barang tetapi juga produk jasa. Demikian halnya dalam pendidikan kualitas merupakan bagian penting untuk diperhatikan. Kualitas adalah bagian penting dari seluruh agenda dalam organisasi dan meningkatkan kualitas mungkin adalah tugas yang paling penting yang dihadapi organisasi manapun Kualitas pembelajaran adalah suatu usaha untuk memenuhi dan memuaskan kebutuhan pelanggan dalam mewujudkan suasana belajar melalui tahap input (sekolah, guru, siswa, visi, misi dan sasaran yang ingin dicapai sekolah), proses (proses pembelajaran, prestasi sekolah, dan prestasi akademik), dan lulusan yang berkualitas sesuai yang diharapkan oleh pelanggan eksternal maupun internal.

Kinerja adalah produk yang dihasilkan oleh seorang pegawai dalam satuan waktu yang telah ditentukan dengan kriteria yang ditentukan pula. Kinerja menurut prawirosentono adalah usaha yang dilakukan dari hasil kerja yang dapat dicapai oleh seseorang atau oleh sekelompok orang dalam suatu organisasi sesuai dengan wewenang dan tanggung jawab masing-masing dalam rangka mencapai tujuan organisasi bersangkutan secara legal, tidak melanggar hukum dan sesuai dengan moral maupun etika.

Dalam bukunya yang berjudul "Kepemimpinan Kepala Sekolah" (Wahdjosumidjo, 2013) mendefinisikan kepala sekolah adalah seorang tenaga fungsional guru yang diberi tugas untuk memimpin suatu sekolah dimana diselenggarakan proses belajar mengajar, atau tempat dimana terjadi interaksi antara guru yang memberi pelajaran dengan murid yang menerima pelajaran. Sedangkan menurut (Daryanto, 2001) kepala sekolah merupakan personel sekolah yang bertanggung jawab terhadap seluruh kegiatan-kegiatan sekolah.

(Ibrahim Bafadal, 2012) pemimpin adalah seseorang yang mampu mempengaruhi orang lain untuk melakukan atau tidak melakukan sesuatu yang diinginkan. Itu artinya bahwa kepala sekolah sebagai pemimpin, ia adalah orang yang memiliki kewenangan dan kemampuan untuk mengendalikan para guru, siswa dan orang lain yang ada disekitarnya agar dengan sukarela, dan tanpa merasa dipaksan secara bersama sama berusaha mencapai tujuan pendidikan yang ada disekolah yang telah ditentukan dan disepakati bersama.

Dengan ini Ahli (Syaiful Sagala, 2009) mengatakan sebagai seorang pemimpin, kepala sekolah perlu memiliki kompetensi-kompetensi seperti kompetensi kepala sekolahial, personal, supervisi, sosial, kewirausahaan, kepribadian, dan emosi. Selain itu seorang kepala sekolah juga harus memiliki perilaku positif seperti yang dijelaskan oleh Syaiful Sagala bahwa kepala sekolah sebagai pemimpin yang dikagumi memiliki 10 watak positif yakni jujur, kompeten, melihat ke depan, selalu memicu inspirasi, pandai dan cerdas, objektif dan berlaku adil, berwawasan luas, berani mengambil resiko, tidak basa-basi langsung pada persoalan, penuh imajinasi. Watak positif ini menggambarkan bahwa integritas kepala sekolah menjadi sangat teruji sehingga menjadi kepala sekolah yang visioner, berjiwa entrepreneur, akomodatif, dan komunikatif. Melalui 10 watak positif tersebut, maka seorang kepala sekolah dapat menjadi suri teladan bagi warga sekolah yang dipimpinnya, sebagaimana yang telah dicontohkan dalam kepemimpinan Rasulullah SAW sebagai figur pemimpin ideal dalam Islam.

Kepala sekolah tidak hanya bertanggung jawab atas kelancaran atas jalannya sekolah secara teknis akademis saja, tetapi segala kegiatan, keadaan lingkungan sekolah dengan kondisi serta situasi serta hubungan dengan masyarakat sekitarnya merupakan tanggung jawabnya pula. Sebab inisiatif dan kreatif yang mengarah pada perkembangan dan kemajuan sekolah merupakan tugas dan tanggung jawab kepala sekolah. Maka dari itu, sebagai pemimpin pendidikan kepala sekolah harus mengetahui dan menjalankan peran serta fungsinya sebagai kepala sekolah. Menurut (E Mulyasa, 2006) kepala sekolah harus mampu berfungsi sebagai educator, kepala sekolah, administrator, supervisor, leader, innovator dan motivator (EMASLIM).

Menurut Sumidjo dalam (E Mulyasa, 2006) memahami arti pendidik tidak cukup berpegang pada konotasi yang terkandung dalam definisi pendidik melainkan harus dipelajari keterkaitannya dengan makna pendidikan, sarana pendidikan dan bagaimana strategi pendidikan itu dilaksanakan. Untuk kepentingan tersebut kepala sekolah harus berusaha menanamkan, memajukan, dan meningkatkan sedikitnya empat macam nilai, yakni pembinaan mental, moral, fisik, dan artistik.

Priansa dan Somad menyampaikan bahwa: Kualitas pendidikan adalah mengacu pada proses pendidikan dan hasil pendidikan. Karena dalam setiap proses pendidikan ada bahan ajar, metodologi, sarana sekolah, dukungan administrasi dan sarana prasarana dan sumber daya lainnya serta penciptaan suasana kondusif sehingga hasil pendidikan yang mengacu pada prestasi akan dapat dicapai oleh sekolah pada kurun waktu tertentu. (Engkoswara dan komariah, 2015) juga mengemukakan bahwa: Kualitas berarti bicara tentang sesuatu barang atau jasa. Barang yang berkualitas adalah barang yang sangat bernilai bagi sesorang, barang tersebut secara fisik sangat bagus, indah, elegan, mewah, antik, kuat, ada kebaikan, keindahan dan idealitas. (Amtu, 2013) juga mengemukakan bahwa: Konsep kualitas (kualitas) menjadi suatu kenyataan dan fenomena dalam seluruh aspek dan dinamika masyarakat, di mana dunia pendidikan di mulai tertantang untuk menereapkan kualitas lulusan yang mampu menjawab kebutuhan pasar kerja dan faktor kualitas menjadi 
sangat menetukan tingkat partisipasi dan kepercayaan masyarakat terhadap suatu lembaga pendidikan.

(Nur, Harun, Ibrahim, 2009) juga mengemukakan bahwa: Kualitas dan perspektif pendidikan adalah kualitas dalam konsep relatif, terutama berhubungan dengan kepuasan pelanggan. Ada pelanggan internal dan ada pelanggan eksternal. Pelanggan internal yaitu kepala sekolah, guru dan karyawan sekolah, sedangkan pelanggan eksternal adalah peserta didik, orang tua, pemeimpin pemerintah dan perusahaan, pasar dan masyarakat luas.

Berdasarkan yang terjadi dilapangan, menunjukkan bahwa kemampuan kepala sekolah pendidikan di sekolah SMA Negeri 1 Kota Jambi, sudah optimal dalam peningkatan kualitas pembelajarannya, salah satu tugas dari kepala sekolah adalah menjadi seorang kepala sekolah, yang mana salah satu tugas kepala sekolah adalah meningkatkan kualitas pembelajaran disekolah, hal ini menarik perhatian saya sebagai kepala sekolah yang baru di SMA 1 Kota Jambi. Dimana dulunya sekolah ini menjadi sekolah favorit memilki segudang prestasi, yang memiliki kapasitas siswa diatas rata-rata dan sangat menarik perhatian orang tua untuk menyekolahkan anaknya di sekolah ini, namun yang terjadi sekarang, orang lebih memilih masuk kesekolah lain dari pada sekolah ini.

Saat ini SMA Negeri 1 Kota Jambi ini mengalami kemunduran karena tidak ada lagi prestasi yang dicapai seperti dulu, sudah jarang terdengar di sekolah ini mengikuti perlombaan baik dibidang ekstrakurikuler, olimpiade cerdas cermat maupun bidang pendidikan lainnya yang meraih prestasi. Berdasarkan fenomena yang terjadi saat ini maka perlu adanya proses peningkatan kualitas pembelajaran yang harus dilakukan oleh guru dan kepala sekolah. Kepala sekolah selaku kepala sekolah di lingkungan sekolah tersebut harus mampu melakukan penilaian terhadap hasil belajar mengajar yang dilakukan oleh guru dan siswa, sehingga dari hasil pengawasan yang dilakukan oleh kepala sekolah secara baik dapat meningkatkan kualitas pembelajaran dan dapat mencapai target yang telah direncanakan.

\section{METODE \\ Jenis Penelitian}

Penelitian ini mengunakan penelitian kualitatif, penelitian kualitatif adalah suatu penelitian dengan mengumpulkan data di lapangan dan menganalisis serta menarik kesimpulan dari data tersebut. Pendekatan kualitatif yaitu "suatu prosedur penelitian yang menghasilkan data deskriptif berupa tulisan dan prilaku yang dapat diamati dari subyek itu sendiri. Pada dasarnya metode kualitatif memiliki beberapa ciri yang sangat jelas, yaitu antara lain:

1) Desain penelitian bersifat lentur dan terbuka

2) Data penelitian diambil dari latar alami
3) Data yang dikumpulkan berupa data deskriptif

4) Lebih meningkatkan proses dari pada hasil

5) Sangat mementingkan makna.

6) Analisis data dilakukan pada saat dan setelah pengumpulan data.

Kesimpulan dari penelitian kualitatif dikonfirmasikan dengan informasi. Sedangkan jenis penelitian yang digunakan adalah studi kasus yaitu merupakan pengujian secara rinci terhadap, suatu latar, satu subyek, satu tempat penyimpanan, atau satu peristiwa tertentu. Dalam penelitian ini studi kasus dititik beratkan pada kinerja kepala sekolah dalam mmeningkatkan kualitas pembelajaran di SMA Negeri 1 Kota Jambi.

\section{Lokasi Penelitian}

Lokasi penelitian ini berada di SMA Negeri 1 Kota Jambi dengan fokus penelitian tentang kinerja kepala sekolah dalam meningkatkan kualitas pembelajaran tahun 2017/2018. Peneliti baru menjabat disana setelah di pahami keadaan yang sebenarnya maka peneliti fikir bahwa sekolah tersebut kepemimpinan kepala sekolah masih belum maksimal dalam meningkatkan kualitas pembelajarannya.

\section{Subjek Penelitian.}

Menurut Faisal yang di cetuskan dalam buku Suharsimi Arikunto: subjek dalam penelitian adalah menunjuk pada orang, individu, kelompok yang dijadikan unit atau satuan yang akan diteliti. Sedangkan Suharsimi Arikunto lebih lanjut menjelaskan bahwa: subjek dalam penelitian adalah benda, keadaan atau orang tempat data melekat dipermasalahkan. Teknik penentuan subjek penelitian menggunakan purposive sampling, teknik ini digunakan peneliti jika memiliki pertimbangan-pertimbangan tertentu dalam pengambilan sampelnya.

Subjek yang akan di ambil dalam penelitian ini adalah kepala kepala sekolah, satu guru dan waka kurikulum. Alasan peneliti akan menjadikan kepala sekolah, guru dan waka kurikulum sebagai objek, karena kepala sekolah merupakan objek yang sangat berperan dalam penelitian ini, dalam peningkatan kualitas pembelajaran.

\section{Teknik Pengumpulan Data}

Teknik pengumpulan data merupakan langkah yang paling utama dalam penelitian karena tujuan utama dari penelitian ialah mendapatkan data. Tanpa mengetahui teknik/metode pengumpulan data maka peneliti tidak mendapatkan data yang memenuhi standar data yang ditetapkan. Teknik yang peneliti gunakan yaitu: observasi, wawancara dan dokumentasi. 


\section{Observasi}

Observasi adalah "suatu cara pengumpulan data dengan pengamatan langsung dan pencatatan secara sistematis terhadap objek yang akan diteliti". Observasi dilakukan oleh peneliti dengan cara pengamatan langsung ke lapangan.

\section{Wawancara}

Wawancara merupakan "salah satu teknik pengumpulan informasi yang di lakukan dengan mengadakan tanya jawab, baik secara langsung maupun tidak langsung."4 Wawancara ini berpedoman kepada daftar pertanyaan yang sudah disiapkan oleh penulis/peneliti. Wawancara dilakukan dengan kepala sekolah dan guru.

\section{Dokumentasi}

Dokumentasi adalah "teknik yang digunakan untuk mencari data mengenai hal-hal atau variabel yang berupa catatan, transkip, buku, surat kabar, majalah, dan sebagainya. Dokumen merupakan catatan peristiwa lampau. Dokumenbiasa berbentuk tulisan, gambar atau karya-karya monumental dari seseorang". Studi dokumen merupakan pelengkap dari penggunaan metode observasi dan wawancara dalam penelitian kualitatif. Teknik dokumentasi dalam penelitian ini digunakan untuk mendapatkan data tentang kinerja kepala sekolah dalam meningkatkan kualitas pembelajaran di SMA Negeri 1 Kota Jambi.

\section{Teknik Analisa Data}

Analisis data dalam sebuah penelitian merupakan "bagian yang sangat penting karena dengan analisis inilah data yang ada nampak manfaatnya terutama dalam memecahkan masalah penelitian dan mencapai tujuan akhir dalam penelitian".6 Menurut (Nasution, 2003) yang dikutip oleh (Sugiyono, 2014) "Analisis telah dimulai sejak merumuskan dan menjelaskan masalah, sebelum terjun ke lapangan dan berlangsung terus sampai penulisan hasil penelitian.

Analisis data pada penelitian ini, peneliti menggunakan analisi menurut Miles dan Huberman yang mengandung empat komponen yang saling berkaitan, yaitu: pengumpulan data, reduksi data, display data, Verifikasi dan Penegasan Kesimpulan (Conclution Drawing and Verification), Adapun langkah-langkah dalam analisis data tersebut, sebagai berikut:

a) Pengumpulandata (Data Collection), merupakan bagian integral dari kegiatan analisis data. Kegiatan pengumpulan data pada penelitian ini adalah dengan menggunakan wawancara dan studi dokumentasi.

b) Reduksidata (Data Reduction), diartikan sebagai proses pemilihan, pemusatan perhatian pada penyederhanaan dan transformasi data kasar yang muncul dari catatan-catatan tertulis di lapangan. Reduksi dilakukan sejak pengumpulan data dimulai dengan membuat ringkasan, mengkode, menelusur tema, membuat gugus-gugus, menulis memo dan sebagainya dengan maksud menyisihkan data / informasi yang tidak relevan.

c) Display data, adalah pendeskripsian sekumpulan informasi tersusun yang memberikan kemungkinan adanya penarikan kesimpulan dan pengambilan tindakan. Penyajian data kualitatif disajikan dalam bentuk teks naratif. Penyajiannya juga dapat berbentuk matrik, diagram, table dan bagan.

d) Verifikasi dan Penegasan Kesimpulan (Conclution Drawing andVerification), Merupakan kegiatan akhir dari analisis data. Penarikan kesimpulan berupa kegiatan interpretasi, yaitu menemukan makna data yang telah disajikan.

Antara display data dan penarikan kesimpulan terdapat aktivitas analisis data yang ada. Dalam pengertian ini analisis data kualitatif merupakan upaya berlanjut, berulang dan terus-menerus. Masalah reduksi data, penyajian data dan penarikan kesimpulan/verifikasi menjadi gambaran keberhasilan secara berurutan sebagai rangkaian kegiatan analisis yang terkait.

\section{HASIL DAN PEMBAHASAN Pengolahan Data}

Hasil penelitian ini diperoleh dari observasi, wawancara dan dokumentasi. Wawancara yang dilakukan oleh peneliti yaitu dengan satu satu orang guru dan satu orang waka kurikulum tentang kinerja kepala sekolah, dan kendala yang dihadapi dalam proses peningkatan kulitas pembelajaran yang ada di SMA Negeri 1 Kota Jambi.

\section{Bagaimana bentuk kinerja kepala sekolah dalam meningkatkan kualitas pembelajaran di SMA Negeri 1 Kota Jambi}

\section{Kinerja kepala sekolah}

a. Peneliti melakukan program kinerja untuk meningkatkan kualitas guru di SMA Negeri 1 Kota Jambi yaitu sebagai berikut:

1) langkah pertama terapkan disini adalah meningkatkan kemampuan guru melalui pembinaan dalam proses pembelajaran.

2) Langkah yang kedua, adalah meningkatkan disiplin guru atau meneggakkan kedisiplinan guru, meningkatkan standar prilaku guru dan melaksanakan semua peraturan.

3) Langkah yang ketiga, meningkatkan motivasi guru yaitu menciptakan situasi yang harmonis, memenuhi semua kelengkapan yang diperlukan serta memberikan penghargaan dan hukuman.

4) Langkah keempat, saya mengadakan pelatihan, mendatangkan tutor kesekolah dan memberikan kesempatan untuk melanjutkan pendidikan, menetapkan guru sesuai dengan bidangnya, dan mengadakan rapat setiap setiap awal semester. 
b. Program yang saya realisasiskan di SMA Negeri 1 Kota Jambi dalam pencapaian visi misi sekolah yaitu : menyusun perencanaan sekolah untuk berbagai tingkat perencanaan, mengembangkan organisasi sekolah sesuai kebutuhan, memimpin sekolah dalam rangka pendayagunaan sumber daya sekolah secara optimal, mengelola perubahan dan pengembangan sekolah menuju organisasi pembelajaran yang efektif, mengelola sarana dan prasarana sekolah dalam rangka pendayagunaan secara optimal, mengelola peserta didik dan penempatan dan pengembangan kapasitas peserta didik, mengelola pengembangan kurikulumdan kegiatan pembelajaran sesuai arah dan tujuan pendidikan nasional, melakukan monitoring, evaluasi dan pelaporan pelaksanaan program kegiatan sekolah dengan prosedur yang tepat, serta merencanakan tindak lanjutnya.

c. mencapai sasaran sekolah, disini guru yang sangat berperan dalam mencapai sasaran itu. Jadi kedepannya Peneliti merencanakan:

1) pertama saya akan melihat tingkat penguasaan guru terhap bahan pelajaran dan penguasaan struktur konsep-konsep keilmuannya.

2) kedua saya akan melihat metode atau pendekatan apa yang digunakan untuk fasilitas belajar yang efektif dan efisisen dan selanjutnya saya melihat pemahaman guru terhadap karakteristik belajar kelompok siswa dengan dialog kreativ dan kemampuan guru untuk menciptakan suasana belajar yang menyenangkan.

d. strategi peneliti dalam mengelola serta memberdayagunakan sarana prasarana sekolah dengan efektif bagi guru dan peserta didik dimana peneliti harus terjun lansung dalam menciptakan lingkungan yang kondusif untuk kelancaran belajar mengajar:

1) pertama yang harus saya lihat itu di dalam ruang kelas, di ruang kelas yang harus dilihat yaitu penerangnya, apakah ada mendapat cahaya yang baik, karena cahaya sangat penting dalam kelangsungan belajar mengajar.

2) Kedua yaitu ventilasi dan suhu udaranya, akan tetapi di sekolah ini tidak menggunakan $\mathrm{AC}$ di ruang kelas, Cuma menggunakan jendela biasa untuk mengatur suhu udaranya.

3) ruang kelas harus jauh dari kebisingan. Karena suara yang bising dapat mengganggu konsentrasi belajar siswa, dan juga perlengkapan belajar sisiwa harus dikontrol seperti papan tulis, dan lain sebagainya yang harus ada dalam ruang kelas. Akan tetapi, tidak cukup hanya di dalam ruang. kelas saja, di luar kelas juga harus kita perhatikan seperti adanya tanaman atau pohon-pohon pelindung. e. Proses pengelolaan peserta didik saat ini harus diupayakan untuk memberi pelayanan khusus kepada peserta didik yang mempunyai kreativitas dan juga berbakat yang berbeda agar tujuan pendidikan dapat diarahkan menjadi lebih baik, dan mengembangkan potensi siswa secara optimal yang meliputi bakat dan minat siswa untuk mewujudkan ketahanan sekolah sebagai lingkungan pendidikan sehingga terhindar dari pengaruh negatif dan bertentangan dengan tujuan pendidikan, jadi dengan banyak siswa yang berbakat atau kreativ kita dapat mempromosikan prestasiprestasi yang telah dicapai tersebut untuk enarik orang masuk kesekolah ini, dengan begitu akan meningkat kapasitas siswa yang masuk ke sekolah ini.

f. Kurikulum yang digunakan dalam proses pembelajaran di SMA Negeri 1 Kota Jambi menggunakan kurikulum 2013, itu sangat ditekankan terlebih dahulu kepada guru yaitu berupa kurikulum yang harus dijalankan seperti sekarang, dan juga guru-guru harus diberikan pelatihan-pelatihan terlebih dahulu. Selanjutnya juga kita harus melihat struktur-struktur kurikulum tersebut apa-apa saja, yaitu beberapa mata pelajaran dan berapa jam minimal seorang guru harus mengajar. Setelah dibagikan semua tugas tugas guru maka saya mengevaluasi kegiatan sejauh mana kegiatan tersebut dijalankan oleh guru-guru tersebut.

g. Sistem IT yang implementasikan oleh guru dalam setiap bidang pembelajaran semua sudah canggih, teknologi adalah kecakapan hidup yang harus dikuasai di era globalisasi ini, jadi guru di sekolah ini juga harus menerapkan sistem IT dalam setiap bidang pembelajarannya, contohnya mencari bahan ajar, referensi belajar, dan sumber informasi bagi para guru dan siswa sehingga dalam pembelajaran peserta didik dapat menggali informasi dari berbagai sumber.

h. perubahan yang terdapat pada perencanaan sekolah dalam meningkatkan kualitas guru kemampuan itu bisa melalui kompetensi pedagogik, kompetensi kepribadian, kompetensi sosial, dan kompetensi profesional, jadi dalam hal ini saya dapat memberikan kesempatan yang luas kepada guru untuk melaksankan kegiatan pengembangan profesi melalui kegiatan pelatihan atau pendidikan, baik yang dilaksanakan oleh sekolah seperti MGMP tingkat sekolah maupun pelatihan yang di luar sekolah seperti kesempatan melanjutkan pendidikan atau mengikuti berbagai kegiatan pelatihan yang diselenggarakan pihak lain.

i. memberdayagunakan sumberdaya yang ada di dalam sekolah sehingga mejadi bermanfaat/pendukung pembelajaran sekolah dalam visi misi sekolah.

1) pertama mengelola komponen organisasi sekolah yang berupa manusia yaitu dengan pengelolaan pengajaran, kesiswaan, dan kepegawaian, 
2) kedua komponen organisasi sekolah yang yang berupa benda yaitu dengan lebih mengaktifkan lagi lab komputer, karena jaman ini jaman globalisasi jadi semua harus mengerti sistem IT, dan sarana prasarana lain seperti lab IPA dan lab bahasa

j. Untuk mengahasilkan lulusan yang berprestasi disini input yang dibutuhkan meliputi guru, peserta didik, tenaga pendidik dan kependidikan, dan kurikulum yang memadai. Dari input inilah kemudian dilakukan proses pembelajaran yang akan menghasilkan output yang berupa lulusan yang berprestasi. Dari lulusan tersebut kemudian akan menghasilkan dampak yang akan menjadi bahan untuk mengkaji kembali apakah visi sudah tercapai dan masih perlu dikembangkan.

k. Dalam mengembangkan organisasi sekolah yang pertama harus adanya pembagian tugas dan tanggung jawab, agar para staf atau karyawan yang ada disekolah ini menjalankan tugas dan memenuhi tanggung jawabnya, dan harus adanya ketertiban dalam organisasi, dengan adanya ketertiban dalam organisasi dapat terlaksana aturan yang ketat untuk terciptanya budaya kerja yang sangat kuat dan memiliki displin kerja yang tinggi dari masingmasing anggota organisasi ini. jadi dengan begitu akan mendapatkan outcome yang bagus dari organisasi ini.

1. Melakukan monitoring kepada guru yang selama ini dilkukan dengan cara melakukan pemantauan, pembinaan dan penyelesaian masalah terhadap pelaksanaan program, dalam pelaksanaannya, monitoring pengaduan dapat dilakukan dalam bekerja sama dengan lembaga-lembaga yang terkait, dan selanjutnya akan menjadi masukan untuk langsung saya tndak lanjutkan.

m. Peningkatan kualitas terutama kali kualitas pembelajaran, yang saya prioritaskan pertama sekali yaitu manajemen waktu, setiap guru yang ada di SMA Negeri 1 Kota Jambi harus dapat memanagement waktu terutama sekali dalam dalam hal mengajar, guru harus bisa tepat waktu masuk kedalam kelas apabila bel sudah berbunyi, itu semua harus ada kontrol dan pengawasan dari kepala sekolah.

n. Supervisi kelas yang dilaksanakan menurut jadwal yang ditentukan.

Adakala melakukan supervisi seminggu sekali dikarenakan banyak guru dan banyak mata pelajaran, dan ditargetkan dalam setahun semua guru harus disupervisi. Supervisi itu bisa dilakukan oleh wakil kepala sekolah yang sudah berkompeten dalam bidang tersebut. Peneliti melakukan supervisi dengan masuk ke kelas langsung dan dalam ruang-ruang guru untuk menyampaikan teknik ketepatan mengajar, materi yang diajarkan sesuai dengan kurikulum yang kita pakai, dan media-media yang dipergunakan juga harus sesuai dengan mata pelajaran, alokasi waktu, sistim penilaian yang harus dilakukan bagaimana. Itu semua tugas saya sebagai kepala sekolah untuk menyampaikan kepada guru. Apalagi jikalau ada guru-guru yang kurang berkompeten dalam menggunakan kurikukum yang kita pakai sekarang.

\section{Hambatan yang di hadapi dalam meningkatkan} kualitas pembelajaran DI SMA Negeri 1 Kota Jambi

1. Kekurangan guru yang profesional.guru yang Negeri saat ini hanya 45 sementara yang dibutuhkan 60 orang guru.

2. Bidang sarana dan prasarana untuk menunjang peningkatan kualitas pembelajaran tidak terlalu besar tetapi juga terdapat kendala, yaitu rungan yang dipakai untuk lab IPA belum memadai dan alat yang dipkai untuk praktikum juga belum memadai. Kalau kendala bagaian peserta didik, ada sebagaian peserta didik yang susah untuk ditangani, itu saya serahkan kebagian waka kesisiwaan, maka apabila mereka juga tidak sanggup untuk menangani saya yang turun tangan untuk memnaggil langsung orang tuanya.

Solusi peneliti yang pertama memenuhi fasilitas sekolah, melakukan penetapan standar nilai, memberi arahan kepada guru maupun peserta didik, melakukan profesionalisme guru melalui kegiatan pendidikan, pelatihan dan memberikan pembinaan khusus bagi peserta didik yang berprestasi, yang kurang berprestasi tetap kita berikan pembinaan akan tetapi pembinaannya beda dengan yang berprestasi.

a. Respon Waka Kurikulum terhadap Kinerja kepala sekolah untuk meningkatkan kualitas pembelajaran di SMA Negeri 1 Kota Jambi.

1) Langkah yang pertama yang terapkan kepala sekolah disini adalah meningkatkan kemampuan guru melalui pembinaan dalam proses pembelajaran. Langkah yang kedua, adalah meningkatkan disiplin guru. Langkah yang ketiga, meningkatkan motivasi guru. Jadi dengan begitu bisa mencipatakan kualitas guru yang ada disini.

2) Langkah pertama yang harus dilakukan kepala sekolah adalah menyusun perencanaan program, sebagaimana yang kita ketahui bahwa suatu hal tidak akan bejalan tannpa adanya perencanaan, selanjutnya kepala sekolah juga mengelola unit layanan pendidikan untuk mendukung kegiatan pembelajaran dan kegiatan peserta didik di sekolah, selanjutnya kepala sekolah juga melakukan monitoring, evaluasi dan pelaporan pelaksanaan program kegiatan sekolah dengan prosedur yang tepat, serta merencanakan tindak lanjutnya.

3) Yang direncanakan oleh kepala sekolah dalam mencapai sasaran sekolah yang pertama adalah melihat tingkat penguasaan guru terhap bahan pelajaran dan penguasaan keilmuannya, dan yang 
kedua melihat metode atau pendekatan apa yang digunakan, selanjutnya adalah mengelola peserta didik dan penempatan dan pengembangan kapasitas peserta didik untuk mencapai sasaran sekolah.

4) Kepala sekolah di SMAN Negeri 1 Kota Jambi ini sangat bertanggung jawab terhadap tugasnya, apa lagi terhadap kelengkapan sarana prasarana beliau selalu mengontrol, karena sarana prasarana ini bertujuan untuk menunjang proses pembelajaran. Beliau selalu terjun langsung untuk melihat kelayakan dan kelengkapan sarana dan prasarana. Misalnya di kelas ada meja atau kursi yang udah rusak atau yang sudah tidak layak pakai itu langsung digantikan dengan yang baru. Akan tetapi, untuk ruang lab ipa itu belim bisa dikatakan memadai, karena alat untuk membuat praktikum juga masih kurang.

5) Di sekolah kami sudah memakai kurikulum 2013, itu sangat ditekankan terlebih dahulu kepada guru yaitu berupa kurikulum yang harus dijalankan seperti sekarang, dan juga guru-guru harus diberikan pelatihan-pelatihan terlebih dahulu. Selanjutnya juga kita harus melihat strukturstruktur kurikulum tersebut apa-apa saja, yaitu beberapa mata pelajaran dan berapa jam minimal seorang guru harus mengajar. Setelah dibagikan semua tugastugas guru maka saya mengevaluasi kegiatan sejauh mana kegiatan tersebut dijalankan oleh guru-gru tersebut.

6) Kualitas guru di sekolah ini masih sangat kurang, kami sangat membutuhkan guru-guru yang kompeten. Masalah sarana dalam pembelajaran juga terdapat kendala, yaitu tidak memadainya laboratorium untuk jurusan IPA, karena sarana yang ada dalam lab IPA kurang memadai dan ruang yang dipakai juga belum memadai. Kendala bagian siswa juga ada, sebagian siswa ada yang susah ditangani dan susah untuk dinasehati

b. Respon Guru terhadap kinerja kepala sekolah untuk meningkatkan kualitas pembelajaran di SMA Negeri 1 Kota Jambi.

1) Langkah pertama yang diterapkan kepala sekolah kami adalah kedisplinan guru, kedisplinan itu adalah hal yang paling utama disini, dan yang kedua adalah motivasi, kepala sekolah sangat memotivasi kami untuk meningkatkan kualitas pendidikan kami sendiri dan kepala sekolah selalu mengadakan pelatihan-pelatihan atau workshop sehingga dengan begitu kami sebagai guru-guru disini akan meningkat kualitas pendidikannya.

2) Program yang kepala sekolah jalankan pada sekolah ini untuk mencapai visi dan misi yang pertama adalah membuat perencanaan, karena tanpa perencanaan semua tidak akan berjalan, yang kedua mengelola sarana dan prasarana sekolah dalam rangka pendayagunaan secara optimal, sarana prasarana sangat penting dalam proses belajar mengajar, dan selanjutnya mengelola pengembangan kurikulumdan kegiatan pembelajaran sesuai arah dan tujuan pendidikan nasional.

3) Kepala sekolah adalah sebagai mediator atau penengah, dalam lingkungan sekolah sebagai suatu organisasi di dalamnya terdapat berbagai macam manusia yang latar belakang yang berbeda-beda. Jadi, melihat tingkat penguasaan guru terhap bahan pelajaran yang digunakan dan selanjutnya melihat pemahaman guru terhadap karakteristik belajar kelompok siswa dan melihat kemampuan guru untuk menciptakan suasana belajar yang efektif dan efisien

4) Kepala sekolah kami sangat bertanggung jawab terhadap tugasnya, salah satunya adalah mengadakan sarana prasarana, apalagi sarana prasarana untuk menunjang proses pembelajaran, beliau terjun langsung untuk mengecek kelengkapan sarana tersebut, untuk di kelas sendiri saya lihat sarananya sudah memadai, hanya saja untuk lab ipa tidak bisa dikatakan memadai karna alat prakteknya belum lengkap.

5) Kendalanya dibagian sarana dalam pembelajaran yaitu tidak memadainya fasilitas, contoh laboratorium untuk jurusan IPA, karena sarana yang ada dalam lab ipa kurang memadai dan ruang yang dipakai juga belum memadai.

\section{Pembahasan \\ Bentuk kinerja kepala sekolah}

Dalam peningkatan kualitas pembelajaran terlihat dari pembinaan, disiplin, meningkatkan kualitas guru bdan mengadakan pelatihan-pelatihan. kinerja kepala sekolah juga dapat dilihat dari kelancaran berfikir, keluwesan berfikir, elaborasi dan originalitas. Ke empat indikator tersebut dapat dijelaskan sebagai berikut:

a. Kelancara berfikir, kepala sekolah dalam meningkatkan kualitas pembelajaran memiliki kelancaran berfikir guna meningkatkan kualitas pembelajaran. Kepala sekolah melakukan langkahlangkah meliputi:menciptakan kualitas guru, merealisasikan pencapaian visi misi,merencanakan pencapaian sasaran, mengelola dan memberdayagunakan sarana prasarana sekolah, pengelolaan peserta didik, pengelolaankurikulum, dan pengimplementasian sistem IT. Langkah-langkah tersebut dapat dijelaskan sebagai berikut:

1) Menciptakan kualitas guru, untuk menciptakan kualitas guru kepala sekolah melakukan beberapa langkah yang meliputi: pembinaan dalam proses pembelajaran, menegakkan kedisiplinan guru, meningkatkan motivasi guru, dan mengadakan pelatihan-pelatihan atau workshop-worksop. 
2) Merealisasikan pencapaian visi misi, untuk merealisasikan pencapaian visi misi kepala sekolah melakukan beberapa program yang meliputi: menyusun perencanaan sekolah, mengembangkan organisasi sesuai dengan kebutuhan, mengelola perubahan dan pengembangan sekolah, mengelola sarana dan prasarana, mengelola peserta didik, mengelola kurikulum, dan melakukan monitoring dan evaluasi.

3) Merencanakan pencapaian sasaran, untuk merencanakan pencapaian sasaran kepala sekolah melakukan perencanaan yang meliputi: tingkat penguasaan guru terhadap bahan ajar, melihat metode atau pendektan apa yang digunakan guru dalam mengajar, dan melihat pemahaman guru terhadap karakteristik belajar siswa.

4) Mengelola dan memberdayagunakan sarana prasarana sekolah, dalam mengelola dan memberdayagunakan sarana prasarana sekolah kepala sekolah mempunyai strategi yang meliputi: menciptakan lingkungan yang kondusif untuk kelancaran belajar mengajar, seperti melihat ruang kelas, yaitu penerangnya, ventilasi dan suhu udaranya,dan ruang kelas harus jauh dari kebisingan.

5) Pengelolaan peserta didik, untuk mengelola peserta didik kepala sekolah mempunyai proses meliputi: memberikan pelayanan khusus untuk peserta didik yang berprestasi, dan mengembangkan potensi siswa secara optimal.

6) pengelolaan kurikulum, dalam pengelolaan kurikulum kepala sekolah mempunyai langkah yang meliputi: memberikan pelatihan-pelatihan untuk guru, melihat struktuk-struktur kurikulum tersebut apa-apa saja, pembagian jam mengajar guru, dan mengevaluasi kegiatan.

7) Peimplementasian sistem IT, dalam pengimplementasian sistem IT kepala sekolah menerapkan: semua guru harus menerapkan sistem IT contohnya, mencari bahan aja, mencari referensi belajar dan mencari informasi-informasi penting.

Hal ini sesuai yang dijelaskan oleh Priansa dan Karwati mengatakan bahwa kualitas pembelajaran akan tercipta apabila penyelenggara pendidikan dapat dilaksanakan secara efektif dalam kerangka kerja yang konseptual. Efektifitas penyelenggaraan pendidikan akan menghasilkn kualitas pendidikan yang diharapkan sesuai visi misi dan tujuan dari sistem pembelajaran yang diselenggarakan di lingkungan sekolah. Hal ini juga dijelaskan oleh E.Mulyasa mengatakan bahwa faktor penting yang besar pengaruhnya terhadap kualitas dalam sebuah sekolah adalah kepala sekolah sebagai pemimpin pendidikan. Kepala sekolah merupakan pimpinan tunggal di sekolah yang mempunyai tanggung jawab untuk mengajar dan mempengaruhi semua pihak yang terlibat dalam kegiatan pendidikan di sekolah untuk bekerja sama dalam mencapai tujuan sekolah. Kepala sekolah dituntut untuk mampu memimpin sekaligus mengorganisir dan mengelola pelaksanaan program belajar mengajar yang dilaksanakan di sekolah yang dipimpinnya.

b. Keluwesan berfikir, kepala sekolah dalam meningkatkan kualitas pembelajaran memiliki keluwesan berfikir guna meningkatkan kualitas pembelajaran, kepala sekolah melakukan langkahlangkah meliputi: menanggapi perubahan dalam peningkatan kualitas guru, memberdayagunakan sumberdaya yang ada untuk pencapaian visi misi, pengelolaan pengembangan pembelajaran untuk menghasilkan lulusan yang berprestasi. Langkahlangkah tersebut dapat dijelaskan sebagai berikut:

1) Menanggapi perubahan dalam meningkatkan kualitas guru, kepala sekolah dalam menanggapi perubahan meningkatkan kualitas guru meliputi: kemampuan melalui kompetensi pedagogik, kompetensi kepribadian, kompetensi sosial dan kompetensi profesional, yang kedua melalui kegiatan pelatihan atau pendidikan baik yang dilaksankan oleh sekolah seperti MGMP, maupun pellatihan yang di luar sekolah seperti kesempatan melanjutkan pendidikan.

2) Memberdayagunakan sumberdaya yang ada untuk pencapaian visi misi, kepala sekolah melakukan memberdayagunakan sumberdaya yang ada untuk pencapaian visi misi meliputi: mengelola komponen organisasi berupa manusia dan yang berupa benda. Yang berupa manusia meliputi pengelolaan pengajaran kesiswaan, dan kepegawaian, yang berupa benda meliputi komputer, sistem IT, dan sarana prasarana.

3) pengelolaan pengembangan pembelajaran untuk menghasilkan lulusan yang berprestasi, kepala sekolah melakukan pengelolaan pengembangan pembelajaran untuk menghasilkan lulusan yang berprestasi meliputi: guru, peserta didik, tenaga penndidik dan kependidikan dan kurikulum yang memadai, dari input inilah kemudian dilakukan proses pembelajaran yang akan menghasilkan output yang berupa lulusan berprestasi.

Hal ini dijelaskan oleh (Jejen Musfah, 2011) mengatakan bahwa: pengembangan guru yang diterapkan kepala sekolah yaitu dengan cara mengikutsertakan guru dalam seminar, diklat dan penataran kependidikan yang diselenggarakan oleh lembaga-lembaga keprofesian. Bahkan dalam hal ini pihak sekolah memberikan keleluasan penuh terrhadap para guru yang akan melanjutkan pendidikan formalnya, kepala sekolah juga berupaya untuk mendorong para guru agar aktif dalam kelompok kerja guru, sehingga diharapkan semua guru mampu mengembangkan 
kemamouannya dalam menjalankan tugas dan tanggung jawabnya sebagai pengajar.

Selanjutnya Jamal Ma`mur Asmani (2009:104) mengatakan bahwa sekolah sebagai lembaga pendidikan formal bertujuan membentuk manusia yang berkepribadian, dalam mengembangkan intelektual peserta didik dalam rangka mencerdaskan kehidupan bangsa. Kepala sekolah sebagai pemimpin perannya sangat penting untuk membantu guru dan karyawan, kegiata utama pendidikan di sekolah adalah dalam rangka mewujudkan tujuannya adalah kegiatan pembelajaran, sehingga seluruh aktivitas organisasi sekolah bermuara pada pencapaian efesiensi dan efektifitas pembelajaran.

Dari paparan diatas maka dapat disimpulkan peningkatan kualitas yaitu dengan melakukan upaya peningkatan kemampuan guru, dalam hal ini yaitu meningkatkan kemampuan guru dalam menjalankan tugas dan kewajibannya sebagai pengajar. Peningkatan kemampuan ini diharapkan mampu untuk meningkatkan kemampuan guru dalam merencanakan, melaksanakan dan menilai hasil pembelajaran yang dilakukannya.

c. Elaborasi, kepala sekolah dalam meningkatkan kualitas pembelajaran memiliki elaborasi guna meningkatkan kualitas pembelajaran, kepala sekolah melakukan langkah-langkah meliputi: mengembangkan organisasi sekolah, pelaksanaan program sekolah. Langkah-langkah tersebut dapat dijelaskan sebagai berikut:

1) Mengembangkan organisasi, kepala sekolah dalam mengembangkan organisasi meliputi: harus adanya pembagian tugas dan tanggung jawab, ketertiban dalam organisasi agar terciptanya budaya kerja yang sangat kuat dan kedisplinan kerja.

2) Pelaksanaan program sekolah, kepala sekolah dalam pelaksanaan program sekolah memiliki halhal yang meliputi: pemantauan pembinaan, penyelesaian masalah terhadap pelaksanaan program, dan harus memiliki displin waktu.

Hal ini juga dijelaskan oleh (Jejen Musfah, 2011) yang mengatakan bahwa Peningkatan kemampuan mengajar guru berimplikasi pada kualitas guru, murid dan sekolah. Murid yang terampil dan kreatif dibentuk oleh budaya sekolah dan kreativitas guru dalam pembelajaran dan lingkungan sekolah, serta dorongan guru kepada murid agar mereka maju dan kreatif. Standar kualitas sebuah sekolah salah satunya diukur oleh kualitas guru, sekolah harus memiliki sistem yang menjamin pengembangan kualitas secara berkelanjutan, sehingga guru terasa nyaman dalam bekerja.

Selanjutnya Nani Rosdijati juga mengatakan bahwa penerapan disiplin sangat penting dilakukan sehubungan dengan rendahnya tingkat kedisplinan guru dan siswa, antara lain yaitu datang terlambat. Pendisplinan dilakukan untuk mengkondisikan semua warga sekolah memiliki kinerja dalam menjalankan tugas dan perannya yang optimal, dimana melalui pendisplinan maka personil sekolah mampu memberikan kinerja yang optimal.

Dari paparan diatas maka dapat disimpulkan bahwa Peningkatan kualitas yang dilakukan oleh kepala sekolah meliputi kemampuan mengajar guru berimplikasi pada kualitas guru, murid dan sekolah. Murid yang terampil dan kreatif dibentuk oleh budaya sekolah dan kreativitas guru dalam pembelajaran dan lingkungan sekolah, serta dorongan guru kepada murid agar mereka maju dan kreatif.

d. Originalitas, kepala sekolah dalam meningkatkan kualitas pembelajaran memiliki originalitas guna meningkatkan kualitas pembelajaran, kepala sekolah melakukan langkah-langkah meliputi: membentuk organisasi untuk pencapaian visi misi sekolah, dan melaksanakan supervisi kelas. Langkah-langkah tersebut dapat dijelaskan sebagai berikut:

1) Membentuk organisasi untuk pencapaian visi misi sekolah, kepala sekolah dalam membentuk organisasi untuk pencapaian visi misi sekolah meliputi:perencanaan, pembinaan pembelajaran, dan manajemen waktu.

2) Melaksanakan supervisi kelas, kepala sekolah dalam melaksanakan supervisi kelas meliputi: supurvisi seminggu sekali dikarenakan banyak mata pelajaran, menyampaikan teknik ketetapan mengajarmateri yang diajarkan sesuai dengan kurikulum yang digunakan, media-media yang digunakan juga harus sesuai dengan mata pelajaran, melaksanakan alokasi waktu dan melakukan sistem penilaian.

Hal ini sesuai yang dijelaskan oleh Made Pidarta, yang menyatakan bahwa jika dipandang dari apa yang ingin dicapai maka hal itu merupakan tujuan supervisi. Jadi tujuan supervisi menunjuk pada apa yang ingin dicapai dari suatu kegiatan, tujuan akhir adalah untuk mencapai pertumbuhan dan perkembangan para siswa yang bersifat total, dan membantu kepala sekolah dalam menyesuaikan program pendidikan dari waktu kewaktu. Adapun teknik-teknik supervisi adalah yang berhubungan dengan kelas yaitu observasi kelas dan kunjungan kelas, dan teknik diskusi yaitu pertemuan formal, pertemuan informal dan rapat guru.

Jadi dapat disimpulkan bahwa teknik-teknik supervisi pendidikan pada dasarnya terdiri dari teknik individu dan kelompok. Teknik individu yaitu kunjungan kelas, observasi kelas dan saling mengunjungi kelas. Jadi efektifitas penyelenggaraan pendidikan akan menghasilkn kualitas pendidikan yang diharapkan sesuai visi misi dan tujuan dari sistem pembelajaran yang diselenggarakan di lingkungan sekolah.

Temuan menunjukkan bahwa kreativitas kepala sekolahial kepala sekolah dalam peningkatan kualitas 
pembelajaran sudah sangat baik. Kepala sekolah sangat berkompeten dalam bidangnya dan bertanggung jawab terhadap tugas-tugasnya. Berbagai kreativitas sudah dilakukan antara lain yaitu yang pertama sekali seperti menciptakan lingkungan yang kondusif untuk proses belajar mengajar siswa, memiliih model pembelaran yang bagus untuk menigkatkan minat belajar siswa, sarana dan prasarana di sekolah dioptimalkan, mengadakan pelatihan-pelatihan untuk guru mengenai pembelajaran guna untuk meningkatan kualitas mengajar guru, dilakukannya supervisi-supervisi kelas dalam seminggu sekali guna untuk mengecek keefektifan mengajar guru.

Selanjutnya Mulyadi mengatakan bahwa dalam upaya peningkatan kualitas pendidikan akan selalu berusaha untuk meningkatkan kualitas lulusan, merupakan suatu mustahil jika pendidikan atau sekolah dapat menghasilkan lulusan yang berkualitas juka tidak melalui proses pendidikan yang berkualitas, pendidikan yang bersifat menyeluruh menyangkut semua komponen pelaksanaan dan kegiatan pendidikan yang disebut sebagai kualitas total.

Dari paparan di atas, maka dapat disimpulkan bahwa untuk meningkatkan kualitas pembelajaran dibutuhkan kreativitas kepala sekolah dengan melakukan berbagai langkah yaitu mengikutsertakan guru dan staf pada kegiatan-kegiatan, seperti pelatihan, penataran, seminar dan workshop-workshop.

\section{Kedala yang dihadapi kepala sekolah dalam meningkatkan kualitas pembelajaran di SMA Negeri 1 Kota Jambi}

Kendala yang dihadapi kepala sekolah dalam peningkatan kualitas pembelajaran yang meliputi kelancaran berfikir, keluwesan berfikir, elaborasi dan originalitas. Ke empat indikator tersebut dapat dijelaskan sebagai berikut:

a. Kelancaran berfikir, adapun kendala yang dihadapi kepala sekolah dalam peningkatan kualitas pembelajaran adalah kurangnya kedisplinan guru, kurangnya partisipasi guru dan minat dalam mengikuti pelatihan, kurangnya sarana dan prasarana dalam menunjang proses pembelajaran, dan masih ada guru yang belum paham sistem IT.

b. Keluwesan berfikir, adapun kendala kepala sekolah dalam keluwesan berfikir adalah kurangnya partisipasi guru dalam mengambil kesempatan melanjutkan pendidikan, kurangnya keaktifan dalam kegiatan pendukung pelaksanaan pengajaran, contohnya lab komputer dan lab bahasa.

c. Elaborasi, adapun kendala kepala sekolan dalam elaborasi adalah kurangnya ketertiban dan kedisplinan kerja, adanya kendala dalampenyelesaian masalah terhadap pelaksanaan program sekolah.

d. Originalitas, adapun kendala kepala sekolah dalam originalitas adalah kurang berjalannya perencanaan yang telah ditetapkan, dan media yang digunakan tidak sesuai dengan mata pelajaran.

\section{SIMPULAN}

Berdasarkan hasil dari penelitian dan pembahasan yang telah penulis kemukakan pada bab IV (hasil peneltian) dapat disimpulkan bahwa:

1. Kepala sekolah dalam konteks penyelenggaraan pendidikan memiliki peran yang sangat strategis sebagai pemimpin. Kepala sekolah bertanggung jawab dalam meningkatkan kualitas pembelajaran. kinerja kepala sekolah dalam peningkatan kualitas pembelajaran sudah sangat baik. Kepala sekolah sebagai pemimpin yang kreatif juga harus meningkatkan kualitas pembelajaran seperti kelancaran berfikir yangmeliputi: menciptakan kualitas guru, merealisasikan pencapaian visi misi, merencanakan pencapaian sasaran, mengelola dan memberdayagunakan sarana dan prasarana sekolah, pengelolaan peserta didik, pengelolaan kurikulum, dan pengimplementasian sistem IT. Selanjutnya kepala sekolah dalam meningkatkan kualitas pembelajaran harus memiliki keluwesan berfikir yang meliputi: menanggapi perubahan dalam peningkatan kualitas guru, memberdayagunakan sumberdaya yang ada untuk pencapaian visi misi, dan pengelolaan hasil pembelajaran untuk menghasilkan lulusan yang berprestasi. Kepala sekolah juga harus memiliki elaborasi guna untuk meningkatkan kualitas pembelajaran yang meliputi: mengembangkan organisasi dan pelaksanaan program sekolah, dan kepala sekolah juga harus memiliki originalitas dalam meningkatkan kualitas pembelajaran yang meliputi: membentuk organisasi untuk pencapaian visi misi sekolah dan melaksanakan supervisi kelas.

2. Kendala yang dihadapi kepala sekolah dalam peningkatan kualitas pembelajaran bersumber dari permasalah guru serta fasilitas pendidikan yang dimiliki sekolah, kurangnya kedisplinan guru, kurangnya partisipasi guru dalam mengambil kesempatan melanjutkan pendidikan, dan kurangnya keaktifan dalam kegiatan pendukung pelaksanaan pengajaran, kurangnya ketertiban dan kedisiplinan, kurang berjalanya perencanaan yang telah ditetapkan dan media yang digunakan belum sesuai dengan mata pelajaran.

\section{Saran}

Berdasarkan Penelitian sekolah yang telah dilakukan, maka penulis dapat menyampaikan saransaran sebagai berikut :

1. Buat Kepala sekolah Lain dalam peningkatan kualitas pembelajaran sudah optimal.Namun kepala sekolah perlu meningkatkan kinerja yang efektif untuk mempimpin sekolah dan motivasi kepada bawahan demi keberhasilan tugas-tugas kepemimpinannya, 
kepala sekolah harus selalu berusaha untuk membina dan mengembangkan kualitas dirinya, yaitu kemampuan dasar kepala sekolahial, sifat dan watak, pengetahuan dan keterampilan profesional, pelatihan dan pengalaman profesional.

2. Kepala sekolah dapat mengatasi kendala dalam kekurangan guru dan kekurangan fasilitas pendidikan untuk menunjang proses pembelajaran,kepala sekolah harus segera melapor ke dinas pendidikan untuk penambahan guru yang pegawai dan juga perlu tindak lanjut dari kepala sekolah dalam rangka penambahan fasilitas pendidikan. Kendala kurangnya guru dan fasilitas pendidikan adalah kendala paling besar dalam pendidikan karena dapat mengakibatkan menurunya kualitas pendidikan.

3. Dalam medukung serta mendorong peningkatan kepala sekolahial kepala sekolah. komite/ wali murid dapat ikut serta baik melalui kemampuan jasa serta materi yang ada yang dimiliki oleh wali murid, cotohnya membuat suatu program guru seperti diklat, seminar, dan workshop yang dapat mendukung kualitas guru dalam proses pembelajaran.

\section{DAFTAR PUSTAKA}

Amtu. (2013) Manajemen pendidikan diera otonomi daerah, konsep, strategidan implementasi. Bandung: Alfabeta

Bafadal, Ibrahim. 2012. Manajemen Peningkatan Mutu Sekolah Dasar. Jakarta: PT Bumi Aksara.

Daryanto. 2001. Administrasi Pendidikan. Jakarta: Rineka Cipta.

Daryanto. (2011). Kepala Sekolah Sebagai Pemimpin Pembelajaran. yogyakarta: Gava Media.

Engkoswara dan Komariah, (2015) Administrasi Pendidikan. Bandung: Alphabeta.

Hosnan. (2014) Pendekatan Saintifik Dan Kontekstual Jakarta : Ghalia Indonesia

Harun. (2009) Manajemen Sumber Daya Pendidikan Yokyakarta : Pena Persada

Moh. Rifai MA, (1982) Administrasi Dan Supervisi Pendidikan Bandung:Jemarss

Mulyasa. E. 2006. Menjadi Kepala Sekolah Profesional. Bandung: Remaja Rosdakarya.

Nasution (2003) Metode Penelitian Naturalistik Kualitatif. Bangdung : Transito.

Prawirosentono, Suryadi. 1999. Kebijakan Kinerja Karyawan, Yogyakarta: BPFE

Sagala, Syaiful. 2009. Konsep dan Makna Pembelajaran. Bandung: Alpahabeta

Sugiyono. (2014). Metode Penelitian Kuantitatif Kualitatif dan $R \& D$. Bandung: Alfabeta.

Suharsimi Arikunto. (2004). Dasar-dasar Supervisi. Jakarta: Rineka Cipta.

Suharsimi Arikunto. (1993) "Manajemen Penelitian", Jakarta : Rhenika Cipta.
Suharisimi Arikunto. (2002) Prosedur Penelitian Suatu Praktek. Jakarta : Rineka Cipta. 